\title{
The Effect of Water Chemistry on Thermochemical Sulfate Reduction: A Case Study from the Ordovician in the Tazhong Area, Northwest China
}

\author{
Hongxia Li, ${ }^{1,2,3,4}$ Chunfang Cai, ${ }^{3,4,5}$ Lianqi Jia, $^{3,4}$ Chenlu Xu, ${ }^{3,4}$ and Ke Zhang ${ }^{6}$ \\ ${ }^{1}$ Research Institute of Unconventional Oil \& Gas, Northeast Petroleum University, Daqing, Heilongjiang 163318, China \\ ${ }^{2}$ Accumulation and Development of Unconventional Oil and Gas, State Key Laboratory Cultivation Base Jointly-Constructed by \\ Heilongjiang Province and the Ministry of Science and Technology, Northeast Petroleum University, Daqing, \\ Heilongjiang 163318, China \\ ${ }^{3}$ Key Lab of Petroleum Resources Research, Institute of Geology and Geophysics, Chinese Academy of Sciences, Beijing 100029, China \\ ${ }^{4}$ University of Chinese Academy of Sciences, Beijing 100049, China \\ ${ }^{5}$ Key Lab of Exploration Technologies for Oil and Gas Resources of Ministry of Education, Yangtze University, Wuhan 430100, China \\ ${ }^{6}$ Research Institute of Petroleum Exploration and Development, Tarim Oilfield Company, PetroChina, Korla, Xinjiang 841000, China
}

Correspondence should be addressed to Chunfang Cai; cai_cf@mail.iggcas.ac.cn

Received 16 February 2017; Revised 15 August 2017; Accepted 5 September 2017; Published 15 October 2017

Academic Editor: Marco Petitta

Copyright (C) 2017 Hongxia Li et al. This is an open access article distributed under the Creative Commons Attribution License, which permits unrestricted use, distribution, and reproduction in any medium, provided the original work is properly cited.

Formation water chemistry, sulfate sulfur isotopes, and associated $\mathrm{H}_{2} \mathrm{~S}$ contents and sulfur isotopes were measured from the Ordovician in Tazhong area, Tarim Basin. The aim is to elucidate the effects of geochemical composition of formation water on thermochemical sulfate reduction (TSR) and potential usage of $\mathrm{SO}_{4} / \mathrm{Cl}$ ratios as a new proxy for TSR extents in areas, where $\mathrm{H}_{2} \mathrm{~S}$ and thiaadamantanes (TAs) data are not available. The formation water has $\mathrm{SO}_{4} / \mathrm{Cl}$ ratios from 0.0002 to 0.016 , significantly lower than 0.04 to 0.05 from 3 to 7 times evapoconcentrated seawater. Thus, the low values are explained to result from TSR. Furthermore, the $\mathrm{SO}_{4} / \mathrm{Cl}$ ratios show negative correlation relationships to TAs and $\mathrm{H}_{2} \mathrm{~S}$ concentrations, indicating that TSR occurred in a relatively closed system and $\mathrm{SO}_{4} / \mathrm{Cl}$ ratio can be used to indicate TSR extents in this area. Extensive TSR in the Cambrian in the Tazhong area, represented by low $\mathrm{SO}_{4} / \mathrm{Cl}$ ratios and high $\mathrm{H}_{2} \mathrm{~S}$ and TAs concentrations, is accompanied by formation water with high TDS and $\mathrm{Mg}$ concentrations, indicating the effects of water chemistry on TSR under a realistic geological background. In contrast, the low TSR extent in the Ordovician may have resulted from limited TSR reaction duration and total contribution of aqueous $\mathrm{SO}_{4}{ }^{2-}$.

\section{Introduction}

Thermochemical sulfate reduction (TSR), a process whereby aqueous sulfate and petroleum compounds react at temperatures higher than $120^{\circ} \mathrm{C}\left(\mathrm{C}_{n} \mathrm{H}_{2 n+2}+\mathrm{SO}_{4}{ }^{2-} \rightarrow \mathrm{CO}_{2}\right.$ $+\mathrm{H}_{2} \mathrm{~S}+$ altered petroleum), is considered to result in elevated $\mathrm{H}_{2} \mathrm{~S}$ concentrations in many carbonate reservoirs [1-8]. Significant advance has occurred on mechanisms of TSR. A great number of organic sulfides such as thiols and thiolanes $[7,9,10]$ and 1 - to 3 -cage thiadiamondoids with 1 to 4 sulfur atoms were detected from TSR areas [11-14]. The presence of these organic sulfur compounds, especially labile sulfur compounds such as 1-pentanethiol or diethyl disulfide, has been experimentally showed to significantly increase the rate of TSR [15]. However, hydrocarbons cannot directly react with solid sulfate in temperature from $180^{\circ} \mathrm{C}$ to $350^{\circ} \mathrm{C}$ in the laboratory [16]. Reactions between solid sulfate and gaseous hydrocarbon are quite slow even under temperatures of several hundred degrees Celsius (Kiyosu et al., 1990). Water is the solvent for chemical species and provides the aqueous matrix for all chemical reactions. Theoretical calculations by $\mathrm{Ma}$ et al. [17] showed that bisulfate ions $\left(\mathrm{HSO}_{4}{ }^{-}\right)$and/or magnesium sulfate contact ion-pairs $\left(\mathrm{MgSO}_{4} \mathrm{CIP}\right)$ are most likely reactive sulfur species involved in TSR. Experiments indicated that the concentrations of $\mathrm{MgSO}_{4}$ CIP are related to temperatures and $\mathrm{SO}_{4} / \mathrm{Mg}$ ratios in the solutions $[18,19]$. 
Consequently, water chemistry and geologic environment can strongly influence the TSR process $[8,17]$. However, the effects of water chemistry on TSR are limited to theoretical and experimental studies. More researches in the real geological setting should be done.

$\mathrm{H}_{2} \mathrm{~S}$, common in the Ordovician carbonate reservoir in the Tazhong area, is generated by TSR [20, 21]. $\mathrm{H}_{2} \mathrm{~S}$ concentration from the Ordovician in the Tazhong area is less than $10 \%$, which is lower than that in the Khuff formation in Abu Dhabi (up to 50\% [6]), the Nisku Formation in western Canada (up to 31\% [22]), and the Feixianguan Formation in the northeastern Sichuan basin (up to $17 \%[23,24]$ ). The low concentrations of $\mathrm{H}_{2} \mathrm{~S}$ in the Tazhong area are considered to result from TSR process which is limited by the burial temperature $[25,26]$. Besides, TSR process can be limited by water chemistry [8]. The Tazhong area is chosen as a research target and compared with the northeastern Sichuan Basin because relatively abundant information about TSR and formation water was published by previous studies. The work presented here seeks to address the following research questions: (1) what is the effect of water chemistry on TSR process and/or extent? (2) Why TSR extent in the Ordovician Yingshan Formation in the Tazhong area is low? A better understanding about the TSR mechanism will be provided through this work.

\section{Geological Setting}

2.1. Structural Units and Stratigraphy. Tazhong area is located in the center of Tazhong Uplift, Tarim Basin, northwest China. It is surrounded by the Manjiaer Sag, South Depression, Bachu Uplift, and Tadong Uplift (Figure 1(a)). It can be divided into number 1 Fault-slope Zone, North Slope, number 10 Structural Belt, Central Faulted Horst Belt, South Slope, and East Burial Hill Zone (Figure 1(b)). Tazhong Uplift is one of the major petroleum production areas in the Tarim Basin. Oils and natural gases have been found in the Cambrian-Ordovician carbonate reservoirs and the SilurianCarboniferous clastic reservoirs [27].

The general stratigraphic columns of the Tazhong area were described previously $[20,25,28,29]$. Briefly, the Cambrian strata are composed of tidal, platform, and platformmarginal carbonates. The Ordovician strata include the Upper Ordovician Sangtanmu $\left(\mathrm{O}_{3} \mathrm{~s}\right)$ and Lianglitage $\left(\mathrm{O}_{3} \mathrm{l}\right)$ Formations and the Lower and Middle Ordovician Yingshan $\left(\mathrm{O}_{1-2} \mathrm{y}\right)$ and Penglaiba $\left(\mathrm{O}_{1} \mathrm{p}\right)$ Formations (Figure 2). The Lower Ordovician is predominantly composed of thick, platform facies dolomite in the lower part and limestone in the upper part. The Upper Ordovician is represented by reef and shoal facies packstone and bioclastic limestone and slope facies limestone and marlstone [9] The Silurian to the Carboniferous sequence consists of marine sandstones and mudstones. The Permian strata are composed of lacustrine sediments and volcanic rocks. The Mesozoic and the Cenozoic are nonmarine sandstones and mudstones [20, 30, 31].

Anhydritic dolomites and anhydrite were observed in supratidal facies of the Middle Cambrian. Bedded anhydrites of $44 \mathrm{~m} \sim 98 \mathrm{~m}$ thick are present in the eastern ZS1 and ZS5 wells [21]. No anhydritic carbonate was observed in the
Ordovician, which makes the geological background of TSR in the Tazhong area differentiate from the northeast Sichuan Basin.

2.2. Burial and Thermal History. TZ12 is located at the central part of number 10 Structural Belt (Figure 1(b)). Based on the burial history that rebuilt on well TZ12 (Figure 3(a)), the Lower Ordovician reached temperature of $120^{\circ} \mathrm{C}$ at the late Cretaceous and then reached to the maximum depth of $5000 \mathrm{~m}$ and temperature of $150^{\circ} \mathrm{C}$ at present day, whereas the Triassic Feixianguan Formation has reached temperature of $150^{\circ} \mathrm{C}$ since the end of the Triassic and reached temperature of $200^{\circ} \mathrm{C}$ at the middle Jurassic (Figure 3(b)). TSR occurred in the limestone reservoirs of the Yingshan Formation above a temperature of $120^{\circ} \mathrm{C}[20,29]$.

\section{Sample Collection and Analysis}

A total of 17 water samples were collected from wells in the Tazhong area. These samples are used for analysis of water chemistry and $\mathrm{S}$ isotopic compositions of $\mathrm{SO}_{4}{ }^{2-} \cdot 7$ $\mathrm{H}_{2} \mathrm{~S}$ samples were collected and analyzed for $\mathrm{S}$ isotope. TAs concentrations in oils are obtained from previous studies.

$\mathrm{pH}$ was measured using an electrode method within 2 hours after sampling in the field. TDS were measured by the gravimetric method according to Clescerl et al. [32]. After filtration with a $0.45 \mathrm{ml}$ filter, $0.5 \mathrm{ml}$ samples of the brines were dried at $180^{\circ} \mathrm{C}$ until a constant weight was reached. The anions were measured by ion chromatography following appropriate dilution (5000 times for $\mathrm{Cl}$ and 1000 times for $\mathrm{Br}$ and $\mathrm{SO}_{4}$ ) with a Dionex ICS900 instrument with an AS19 ion-exchange column. The analytical precisions were better than $0.8 \%$ for $\mathrm{Cl}$ and $4.3 \%$ for $\mathrm{SO}_{4}{ }^{2-}$. The major cations in the diluted solutions (5000 times for all cations) were analyzed with a Varian Vista-Pro inductively coupled plasmaoptical emission spectrometer (ICP-OES) with an analytical precision better than $5 \%$.

Dissolved $\mathrm{SO}_{4}{ }^{2-}$ was quantitatively precipitated as $\mathrm{BaSO}_{4}$ by reacting with excess $\mathrm{BaCl}_{2}$. This reaction was performed at a $\mathrm{pH}$ between 3 and 4 with $\mathrm{HCl}$ to prevent precipitation of $\mathrm{BaCO}_{3}$. The precipitation of $\mathrm{BaSO}_{4}$ was then filtered using a Buchner funnel and washed with distilled water. And then precipitation of $\mathrm{BaSO}_{4}$ was dried and used for sulfur isotopic analysis on a Thermo Finnigan Delta $S$ mass spectrometer. $\mathrm{H}_{2} \mathrm{~S}$ was precipitated immediately in the field by the quantitative reaction with excess zinc acetate, $\mathrm{Zn}\left(\mathrm{CH}_{3} \mathrm{COO}\right)_{2}$, to form $\mathrm{ZnS}$ at a $\mathrm{pH}$ in the range of 10-11 (the $\mathrm{pH}$ was adjusted with $\mathrm{NaOH}$ ). The solution with $\mathrm{ZnS}$ was put aside overnight and then filtered with a $0.45 \mu \mathrm{m}$ filter on site. In the laboratory, $\mathrm{ZnS}$ was transformed to $\mathrm{Ag}_{2} \mathrm{~S}$ by adding $\mathrm{HCl}$ and passing the evolved $\mathrm{H}_{2} \mathrm{~S}$ under an inert atmosphere through $\mathrm{AgNO}_{3}$ solution at a $\mathrm{pH}$ of $4 . \mathrm{Ag}_{2} \mathrm{~S}$ were used for sulfur isotopic analysis on a Thermo Finnigan Delta $S$ mass spectrometer calibrated by a series of International Atomic Energy Agency standards. Results are presented as $\delta^{34} S$ relative to the Vienna Canyon Diablo Troilite (VCDT) standard. The reproducibility for $\delta^{34} S$ measurement is $\pm 0.3 \%$. 

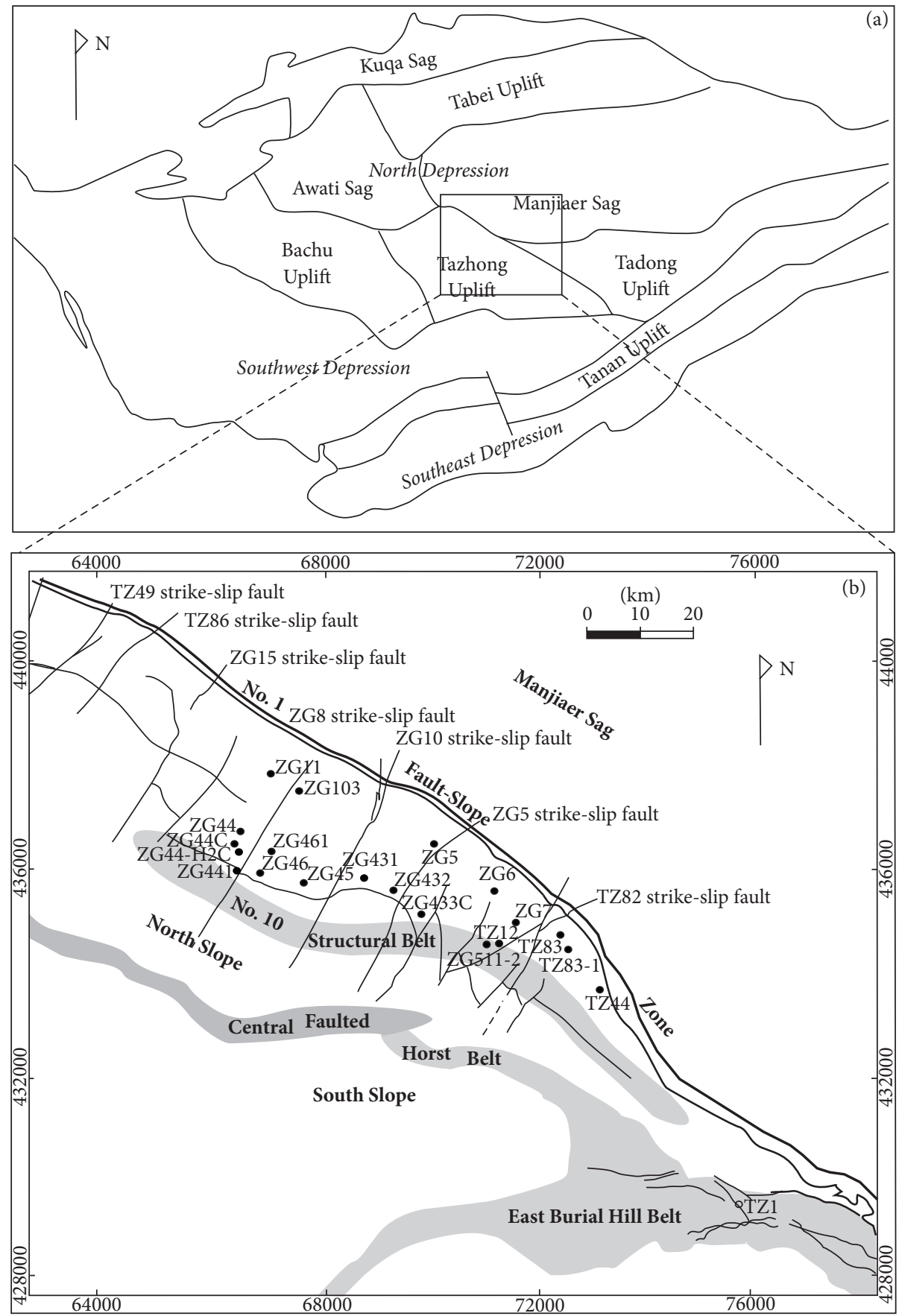

$\mathrm{O}_{1-2} \mathrm{y}$ formation water

Faults

FIgURE 1: (a) Map of the Tarim Basin showing tectonic units and location of Tazhong Uplift; (b) map of the study area showing geological tectonics and location of wells from where formation waters were collected.

\section{Results}

4.1. Water Chemistry. Chemical compositions of formation water are shown in Table 1. The Yingshan Formation $\left(\mathrm{O}_{1-2} \mathrm{y}\right)$ formation waters have $\mathrm{Na}^{+}$concentrations ranging from $20140 \mathrm{mg} / \mathrm{L}$ to $64000 \mathrm{mg} / \mathrm{L}$ and $\mathrm{Cl}^{-}$concentrations ranging from $50861 \mathrm{mg} / \mathrm{L}$ to $126000 \mathrm{mg} / \mathrm{L}$, characterized by $\mathrm{Na} / \mathrm{Cl}$ molar ratios of $0.54 \sim 0.89$ with an average of 0.74 . The range of $\mathrm{SO}_{4}{ }^{2-}$ concentrations is from $31 \mathrm{mg} / \mathrm{L}$ to $891 \mathrm{mg} / \mathrm{L}$. The $\mathrm{SO}_{4} / \mathrm{Cl}$ ratios (expressed in weight units) range from 0.0002 to 0.016 with a mean value of $0.005\left(\mathrm{SO}_{4} / \mathrm{Cl}\right.$ ratio of seawater is 0.144 ). The range of $\mathrm{Mg}^{2+}$ concentrations of 


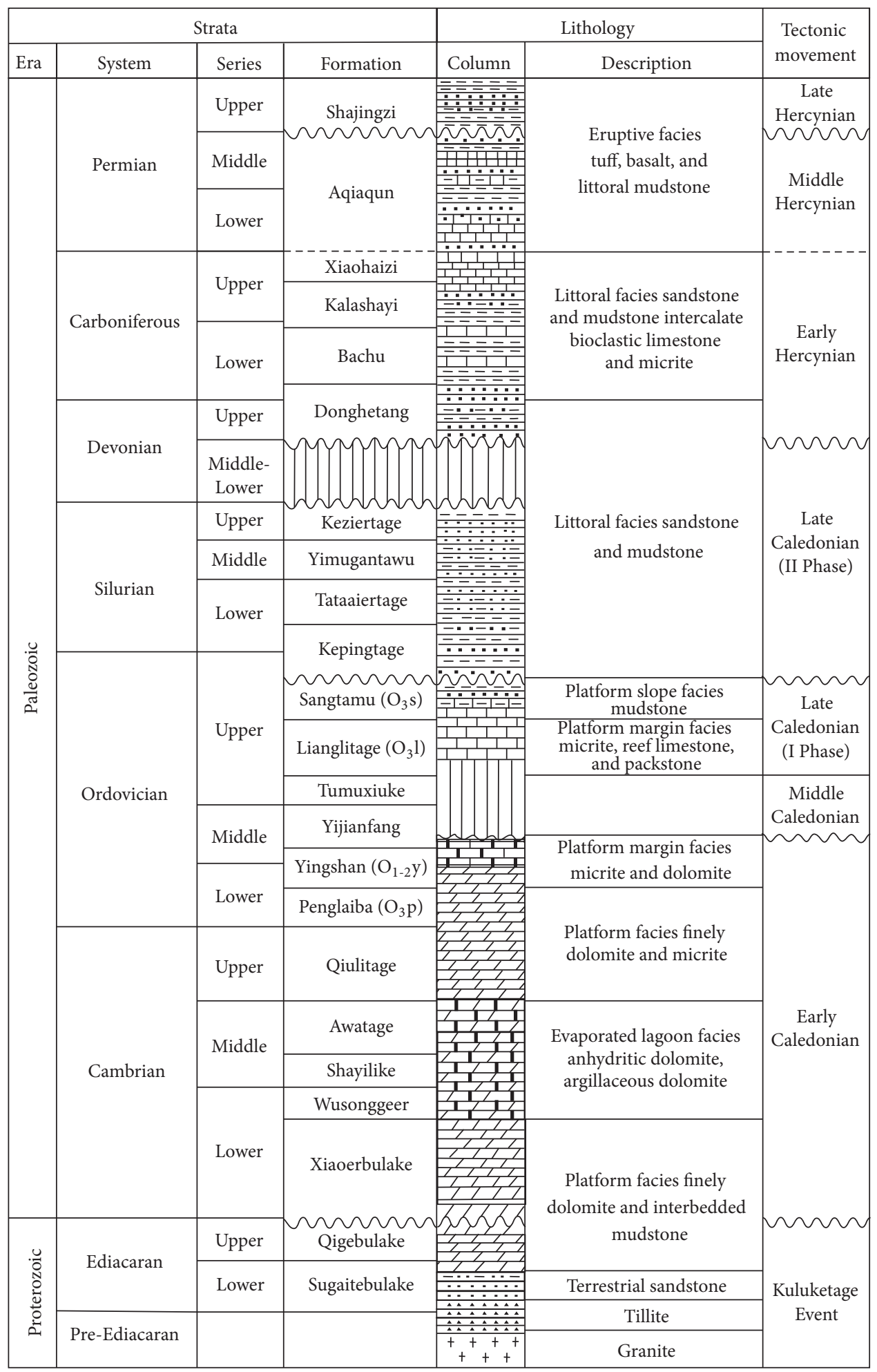

FIgURE 2: Stratigraphic column for the Tazhong Uplift.

$\mathrm{O}_{1-2} \mathrm{y}$ formation waters is from $92 \mathrm{mg} / \mathrm{L}$ to $1070 \mathrm{mg} / \mathrm{L}$ with an average of $638 \mathrm{mg} / \mathrm{L}$, and the $\mathrm{Mg} / \mathrm{Cl}$ ratios lie between 0.002 and 0.014 with a mean value of $0.007(\mathrm{Mg} / \mathrm{Cl}$ ratio of seawater is 0.067$) . \mathrm{Na} / \mathrm{Cl}$ molar ratios of formation water are close to that of seawater (0.86). $\mathrm{SO}_{4} / \mathrm{Cl}$ and $\mathrm{Mg} / \mathrm{Cl}$ ratios of formation water are significantly depleted compared to seawater and vary largely compared to $\mathrm{Na} / \mathrm{Cl}$ molar ratios.

The Cambrian formation water has $\mathrm{SO}_{4}{ }^{2-}$ concentration of $182 \mathrm{mg} / \mathrm{L}, \mathrm{Cl}^{-}$concentration of $164000 \mathrm{mg} / \mathrm{L}, \mathrm{SO}_{4} / \mathrm{Cl}$ ratio of 0.001 which is lower than most of the $\mathrm{O}_{1-2} \mathrm{y}$ formation 


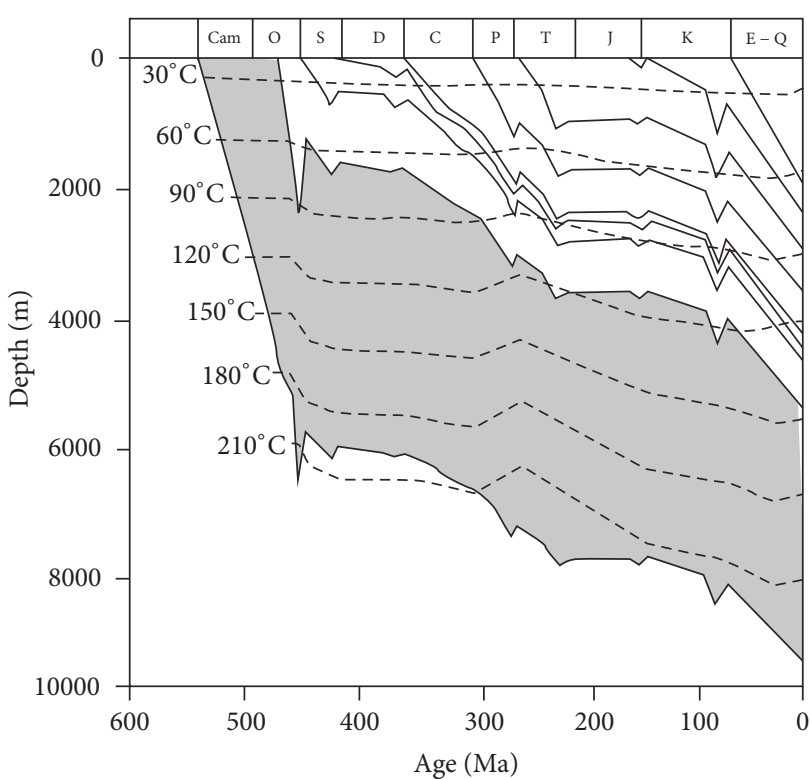

(a)

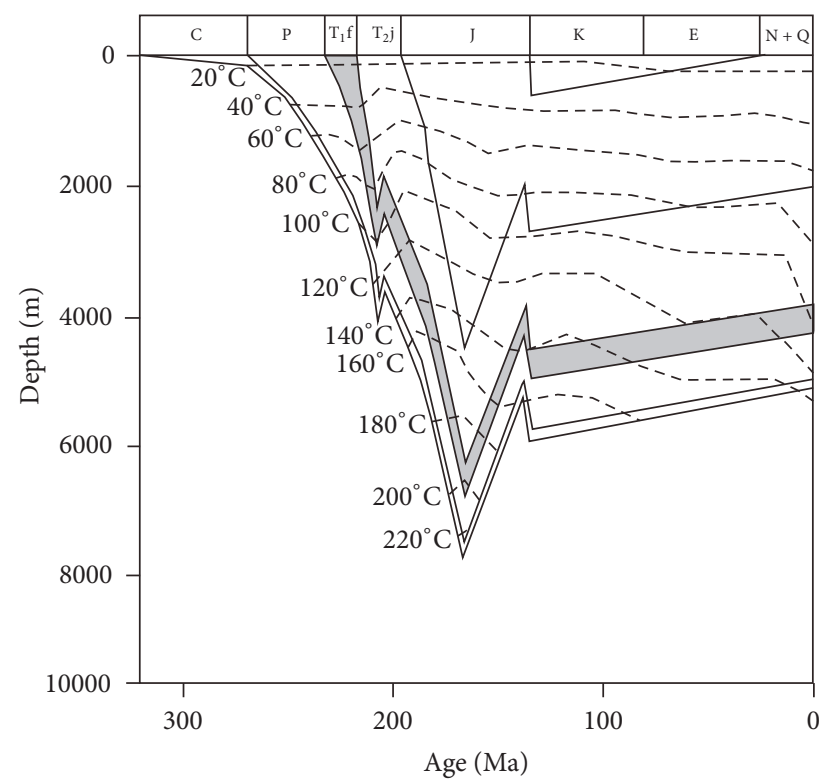

(b)

FIgURE 3: (a) Burial and paleotemperature history of the Ordovician Yingshan Formation (marked with grey color) based on the well TZ12 in the Tazhong area (modified from Chen et al., 2010). (b) Burial and paleotemperature history of the Triassic Feixianguan Formation (marked with grey color) based on the well LJ2 from the Northeast Sichuan Basin (modified from [23]).

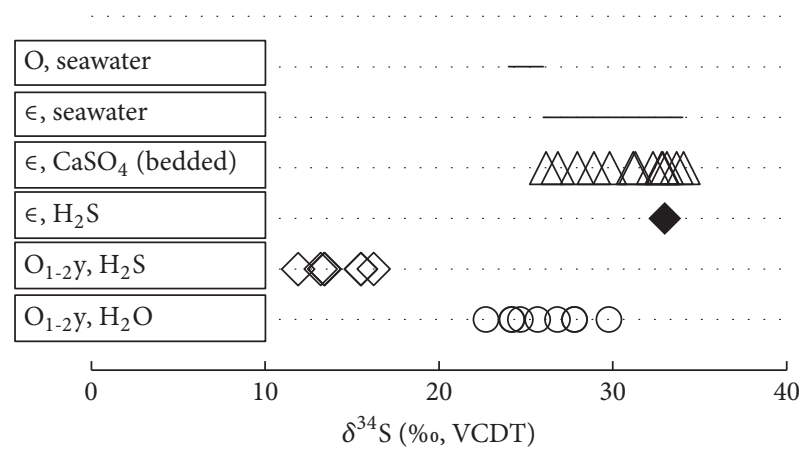

FIGURE 4: Sulfur isotopic composition of water, $\mathrm{H}_{2} \mathrm{~S}$, and anhydrite. Sulfur isotopic of bedded anhydrite is from Cai et al. [10]. Sulfur isotopic of $\mathrm{H}_{2} \mathrm{~S}$ in the Cambrian is from Cai et al. [21].

water. The Cambrian formation water has $\mathrm{Mg}^{2+}$ concentration of $25500 \mathrm{mg} / \mathrm{L}$ and $\mathrm{Mg} / \mathrm{Cl}$ ratios of 0.155 which is higher than that of the $\mathrm{O}_{1-2} \mathrm{y}$ formation water.

4.2. Sulfur Isotopic Composition. $\delta^{34} \mathrm{~S}_{\mathrm{H} 2 \mathrm{~S}}$ values in the $\mathrm{O}_{1-2} \mathrm{Y}$ carbonate reservoir range from $11.9 \%$ to $16.3 \%$ with an average of $14.2 \%$ (Table 1 ). $\delta^{34} \mathrm{~S}$ value of $\mathrm{H}_{2} \mathrm{~S}$ from the Cambrian is $33 \%$ which is significantly higher than that from the $\mathrm{O}_{1-2} \mathrm{y}$ carbonate reservoir. $\delta^{34} \mathrm{~S}_{\mathrm{SO} 4}$ values of the $\mathrm{O}_{1-2} \mathrm{y}$ formation water range from $22.7 \%$ to $29.8 \%$ with an average of $26 \%$ which is slightly heavier than that of coeval seawater (Figure 4). $\delta^{34} \mathrm{~S}$ values of the Cambrian bedded anhydrite lie between $26.2 \%$ and $33.7 \%$, which is similar to the Cambrian seawater. $\delta^{34} \mathrm{~S}$ values of $\mathrm{H}_{2} \mathrm{~S}$ from the Ordovician are lighter than that of the Cambrian seawater, the Ordovician seawater, and the Cambrian bedded anhydrite (Figure 4). Sulfur isotope fractionation between $\mathrm{SO}_{4}$ and $\mathrm{H}_{2} \mathrm{~S}$ in the Ordovician lies between $8.7 \%$ and $12.3 \%$ with an average of $10.6 \%$.

\section{Discussion}

5.1. Sulfur Isotope Composition and Fractionation. $\mathrm{H}_{2} \mathrm{~S}$ from the Ordovician carbonate reservoir in this and previous studies have $\delta^{34} S$ values from $12 \%$ to $16 \%$ which are $15 \%$ $20 \%$ lighter than the counterpart in the Cambrian $(33 \%$ ) $[10,21,34]$. The large differences indicate that the $\mathrm{H}_{2} \mathrm{~S}$ in the Ordovician was probably generated from in situ TSR rather than TSR that happened in the Cambrian $[13,21]$. A positive relationship exists between $\delta^{34} \mathrm{~S}_{\mathrm{H} 2 \mathrm{~S}}$ values and $\delta^{34} \mathrm{~S}_{\mathrm{SO} 4}$ values (Figure $5(\mathrm{a})) . \delta^{34} \mathrm{~S}_{\mathrm{SO} 4}$ values tend to increase with a decrease of $\mathrm{SO}_{4}{ }^{2-}$ concentrations in the formation water (Figure 5(b)). This indicates that $\delta^{34} \mathrm{~S}$ values of $\mathrm{H}_{2} \mathrm{~S}$ are related to those of the remaining $\mathrm{SO}_{4}{ }^{2-}$. There is a positive relationship between $\delta^{34} \mathrm{~S}_{\mathrm{SO} 4-\mathrm{H} 2 \mathrm{~S}}$ and $\mathrm{SO}_{4} / \mathrm{Cl}$ ratios (Figure 5(c)), likely indicating that the more dissolved $\mathrm{SO}_{4}{ }^{2-}$ is converted to $\mathrm{H}_{2} \mathrm{~S}$, the smaller sulfur isotope fractionation occurs. This may imply that $\delta^{34} \mathrm{~S}_{\mathrm{H} 2 \mathrm{~S}}$ values are controlled by both $\delta^{34} \mathrm{~S}_{\mathrm{SO} 4}$ values and TSR extent.

Sulfur isotope fractionation is nearly negligible if complete conversion of the available sulfate during TSR [5] (Krouse, 2001). Sulfur isotope fractionation is observed when only part of sulfate was reduced during TSR [35]. $\mathrm{H}_{2} \mathrm{~S}$ in the Cambrian carbonate reservoir has $\delta^{34} S_{\mathrm{H} 2 \mathrm{~S}}$ values close to coeval bedded anhydrite (Figure 4), whereas $\mathrm{H}_{2} \mathrm{~S}$ in the 


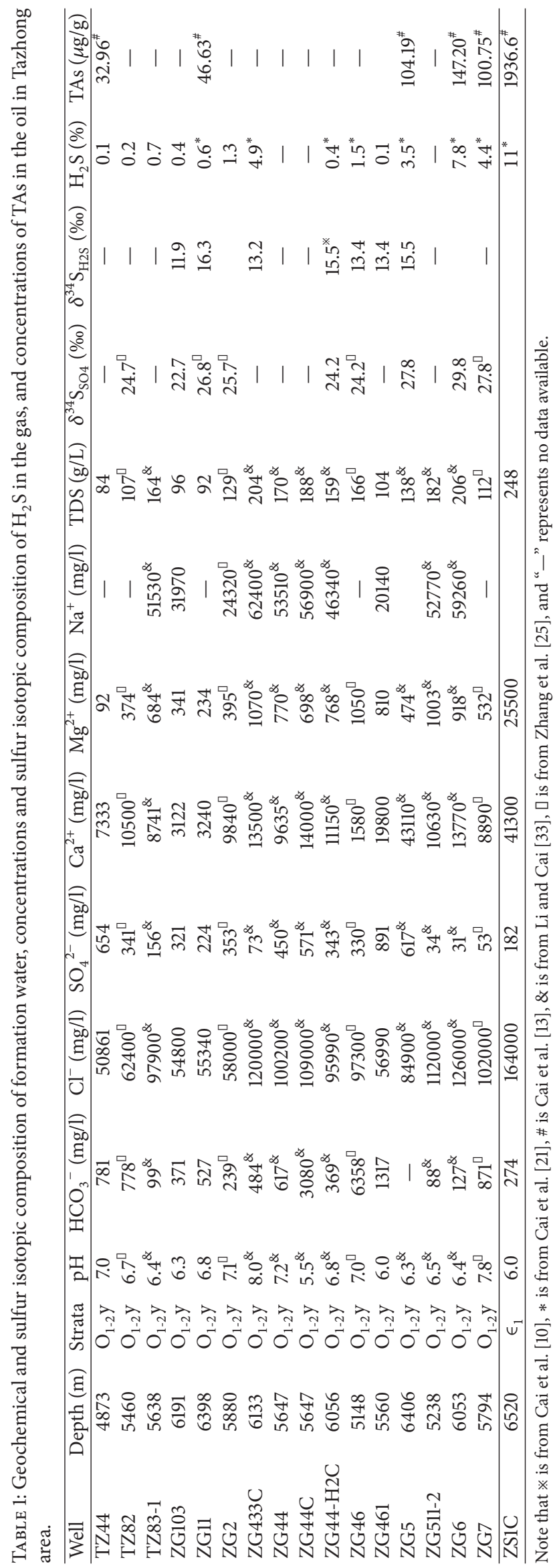




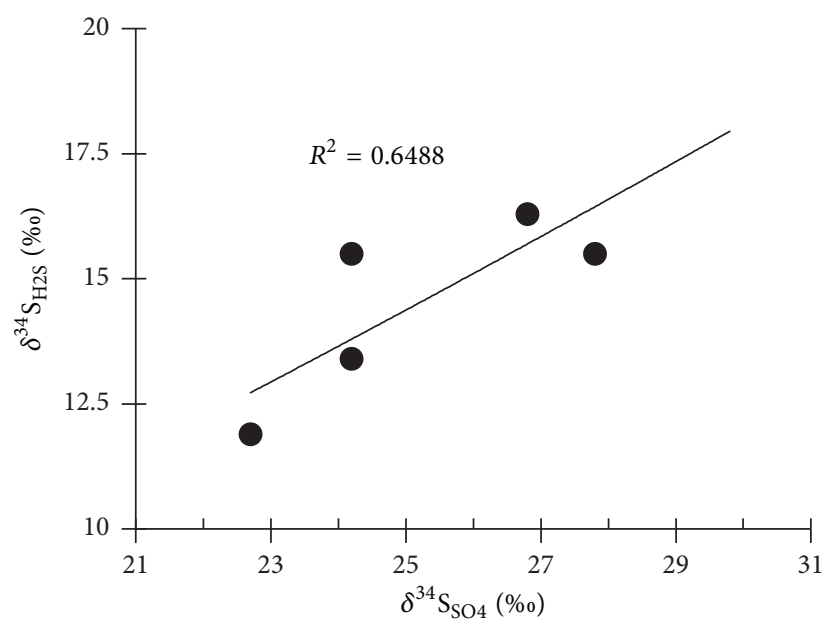

(a)

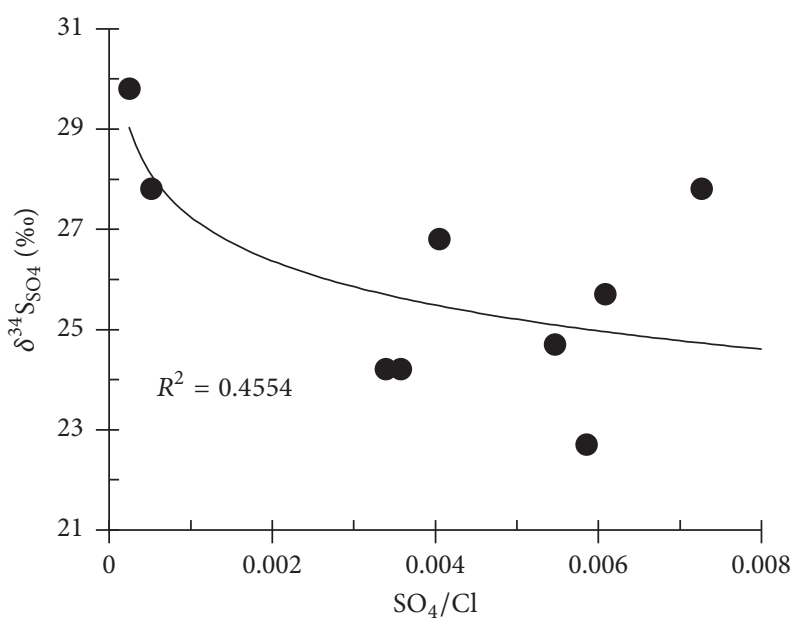

(b)

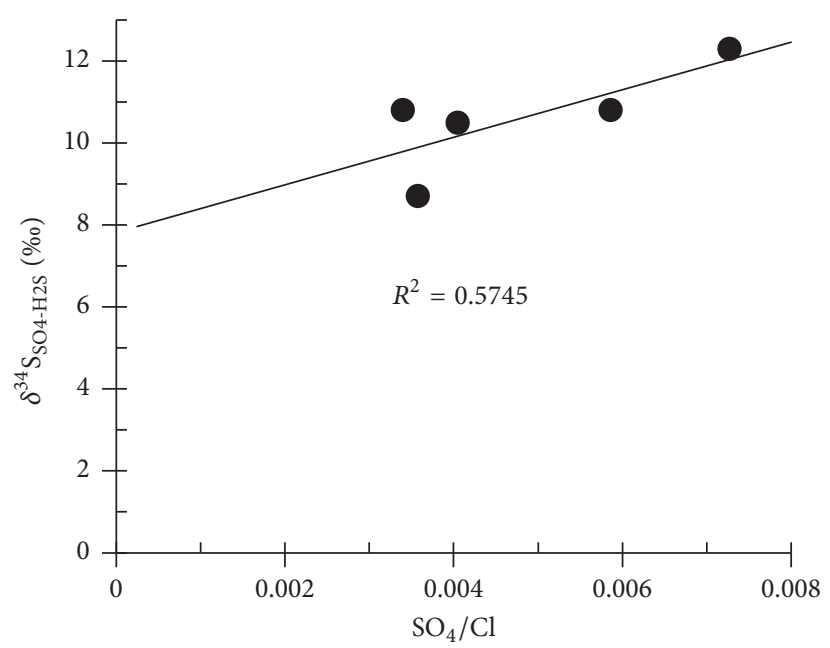

(c)

Figure 5: Relationship between (a) $\delta^{34} \mathrm{~S}_{\mathrm{SO} 4}$ and $\delta^{34} \mathrm{~S}_{\mathrm{H} 2 \mathrm{~S}}$; (b) $\mathrm{SO}_{4} / \mathrm{Cl}$ and $\delta^{34} \mathrm{~S}_{\mathrm{SO} 4}$; (c) $\mathrm{SO}_{4} / \mathrm{Cl}$ and $\delta^{34} \mathrm{~S}_{\mathrm{SO} 4-\mathrm{H} 2 \mathrm{~s}}$.

Ordovician carbonate reservoir has $\delta^{34} \mathrm{~S}_{\mathrm{H} 2 \mathrm{~S}}$ values lighter than coeval seawater $(22 \sim 26 \%$, [36]) and formation water (Figure 4). $\delta^{34} \mathrm{~S}_{\mathrm{SO} 4-\mathrm{H} 2 \mathrm{~S}}$ differences of the Ordovician in the study area fall within a range of $8.7 \%$ o to $12.3 \%$ with a mean value of $10.6 \%$ (Table 1). The differences of $\delta^{34} \mathrm{~S}$ values between $\mathrm{H}_{2} \mathrm{~S}$ and $\mathrm{SO}_{4}{ }^{2-}$ in the Ordovician carbonate reservoir are higher than those of the Khuff Formation (2\%o to $3 \%$; [6]). This is probably due to the different geologic settings between the Abu Dhabi and the Tazhong area. TSR in the Khuff Formation of Abu Dhabi happened in the gas intervals with faster sulfate reduction than supply of reactive sulfates from anhydrite dissolution; consequently, almost all dissolved $\mathrm{SO}_{4}{ }^{2-}$ are converted into $\mathrm{H}_{2} \mathrm{~S}$ and thus $\mathrm{H}_{2} \mathrm{~S}$ shows similar $\delta^{34} \mathrm{~S}$ values to the parent anhydrite [6]. In contrast, TSR in the Tazhong area may have happened at the oilwater transition zone $[13,14,21]$. TSR around the oil-water transition zone may have not consumed all the dissolved $\mathrm{SO}_{4}{ }^{2-} ;{ }^{34} \mathrm{SO}_{4}{ }^{2-}$ may have been reduced preferentially as the result of kinetic isotopic fractionation; thus, significant $\delta^{34} \mathrm{~S}_{\mathrm{SO} 4-\mathrm{H} 2 \mathrm{~S}}$ differences are observed. Similar cases were reported from gas-water transitions in local areas from the western Canadian Basin [5] and the northeastern Sichuan Basin (Cai et al., 2010). The relatively lower $\mathrm{H}_{2} \mathrm{~S}$ concentration and higher $\delta^{34} \mathrm{~S}_{\mathrm{SO} 4-\mathrm{H} 2 \mathrm{~S}}$ differences in the $\mathrm{O}_{1-2} \mathrm{y}$ Formation than those in the Cambrian may indicate that only part of the dissolved $\mathrm{SO}_{4}{ }^{2-}$ was reduced in situ in the Tazhong area, and TSR in the Ordovician is in the early stage. Zhang et al. [25] and Su et al. [26] also suggested that the overall TSR extent in the Ordovician of the Tazhong area is limited by the burial temperatures that reservoirs experienced. In other words, TSR extent is low and dissolved $\mathrm{SO}_{4}{ }^{2-}$ is excessive for in situ TSR in the Ordovician of the Tazhong area. $\mathrm{SO}_{4} / \mathrm{Cl}$ ratios, relating to the remaining dissolved $\mathrm{SO}_{4}{ }^{2-}$ amounts in formation water, probably can be used as a proxy of in situ TSR extent under some circumstances, where $\mathrm{H}_{2} \mathrm{~S}$ and TAs concentrations are unavailable. 


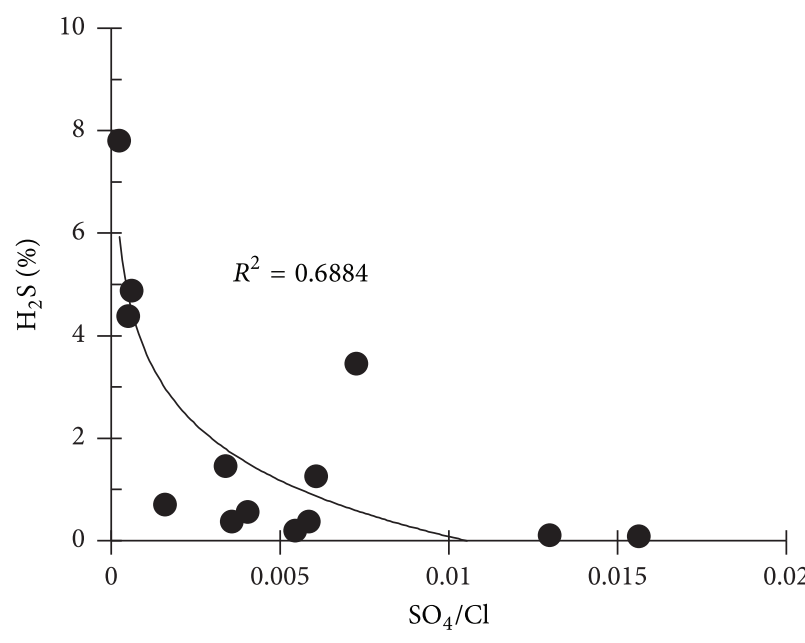

(a)

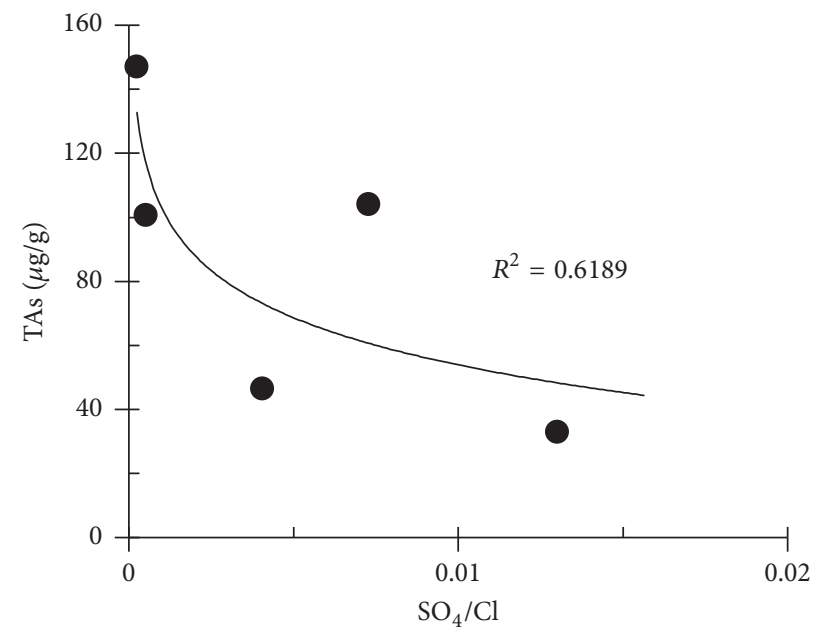

(b)

FIGURE 6: Relationship between (a) $\mathrm{SO}_{4} / \mathrm{Cl}$ ratios and $\mathrm{H}_{2} \mathrm{~S}$ concentrations; (b) $\mathrm{SO}_{4} / \mathrm{Cl}$ ratios and TAs concentrations.

\section{2. $\mathrm{SO}_{4} / \mathrm{Cl}$ Ratio: A Potential Proxy of TSR Extent}

\subsubsection{Effects of Water Evolution on $\mathrm{SO}_{4} / \mathrm{Cl}$ Ratio. When initial} seawater is evaporated and concentrated to 10 times, $\mathrm{SO}_{4} / \mathrm{Cl}$ ratio of seawater decreases from 0.144 to 0.04 as the result of the precipitation of sulfates [37, 38]. TDS of formation water in the study area lies between $84 \mathrm{~g} / \mathrm{L}$ and $206 \mathrm{~g} / \mathrm{L}$ with an average of $144 \mathrm{~g} / \mathrm{L}$, which is 3 to 7 folds of seawater $(35 \mathrm{~g} / \mathrm{L})$. $\mathrm{SO}_{4} / \mathrm{Cl}$ ratios of 3 times and 7 times concentrated seawater are 0.05 and 0.04 , respectively. Whereas the $\mathrm{O}_{1-2} \mathrm{y}$ formation water has $\mathrm{SO}_{4} / \mathrm{Cl}$ ratios from 0.0002 to 0.016 , which are significantly lower than that which can be generated from the seawater evaporation. Assuming that the Cambrian to the Middle Ordovician seawater has a similar $\mathrm{SO}_{4} / \mathrm{Cl}$ ratio, formation waters from both the Cambrian and $\mathrm{O}_{1-2} \mathrm{y}$ evolved from evaporated seawater alone are expected to have $\mathrm{SO}_{4} / \mathrm{Cl}$ ratios higher than 0.04; thus, it is unlikely for the mixing of evaporated formation water between the Cambrian and the $\mathrm{O}_{1-2}$ y Formation to have the low $\mathrm{SO}_{4} / \mathrm{Cl}$ ratios $(<0.016)$.

5.2.2. Consumption of Aqueous $\mathrm{SO}_{4}{ }^{2-}$ by TSR. TSR is ubiquitous in the carbonate reservoirs the Tazhong area $[13,20$, $21,29,39,40]$. TSR in the Cambrian is more extensive than that in the Ordovician, as higher $\mathrm{H}_{2} \mathrm{~S}$ concentration, higher TAs concentration, and lower $\mathrm{SO}_{4} / \mathrm{Cl}$ ratio were observed (Table 1). TSR consumes dissolved $\mathrm{SO}_{4}{ }^{2-}$, leading to lower $\mathrm{SO}_{4} / \mathrm{Cl}$ ratios in the formation water than original seawater. The depletion of $\mathrm{SO}_{4}{ }^{2-}$ in the $\mathrm{O}_{1-2} \mathrm{y}$ formation water was not compensated by anhydrite dissolution as no anhydrite or anhydritic carbonate rocks develop in the Ordovician strata (Figure 2).

$\mathrm{H}_{2} \mathrm{~S}$, a direct product of TSR, can dissolve in formation water, precipitate as pyrite, and be incorporated into oils and solid bitumens producing alkylthiolanes, alkylthiols, and alkyl 2-thiaadamantanes [7, 13, 21]. Thiaadamantanes (TAs) concentrations in petroleum are considered to better reflect TSR extents because TAs is quite stable even under high temperature $[13,14,41]$. However, TAs concentrations are only measured in several wells. Negative relationships exist in $\mathrm{SO}_{4} / \mathrm{Cl}$ ratios versus $\mathrm{H}_{2} \mathrm{~S}$ concentrations and $\mathrm{SO}_{4} / \mathrm{Cl}$ ratios versus TAs concentrations (Figures 6(a) and 6(b)). This indicates that $\mathrm{SO}_{4}{ }^{2-}$ was transformed to $\mathrm{H}_{2} \mathrm{~S}$ by TSR and subsequently to incorporate into TAs in a relatively closed system. Thus, $\mathrm{SO}_{4} / \mathrm{Cl}$ ratio is expected to be a good proxy to reflect TSR extent if they are not significantly changed by water mixing or anhydrite dissolution.

5.3. Influence of Water Chemistry on TSR Initiation. TSR is commonly observed in carbonate reservoirs with hightemperature, but it is difficult to repeat the TSR process in the laboratory under conditions resembling nature. Dissolved $\mathrm{SO}_{4}{ }^{2-}$, with symmetrical molecular structure and spherical electronic distributions, have extremely low reactivity in the absence of catalysis [17]. TSR reactions that occur in natural environments are most likely to involve magnesium sulfate $\left(\mathrm{MgSO}_{4}\right)$ rather than "free" dissolved sulfate ions $\left(\mathrm{SO}_{4}{ }^{2-}\right)$ or solvated sulfate ion-pairs. $\mathrm{MgSO}_{4}$ has been proved to be an effective catalysis for TSR in the laboratory $[17,42] . \mathrm{MgSO}_{4}$ exists as a main magnesium-bearing specie in solutions with $\mathrm{Mg}^{2+}$ being dominant [43]. As temperature increases, $\mathrm{MgSO}_{4}$ solutions were separated into $\mathrm{MgSO}_{4}$-rich phase and $\mathrm{MgSO}_{4}$ poor phase due to the formation of the complex $\mathrm{Mg}^{2+}-\mathrm{SO}_{4}{ }^{2-}$ ion association in the fused silica capillary capsules, and the phase separation temperature decreases with increasing $\mathrm{Mg} / \mathrm{SO}_{4}$ ratios [19]. This indicates that formation water with high $\mathrm{Mg}$ concentrations and high temperature is preferable to form $\mathrm{MgSO}_{4}$ and initiate TSR.

Figures $7(\mathrm{a}), 7(\mathrm{~b})$, and $7(\mathrm{c})$ show a negative relationship between $\mathrm{Mg}$ concentrations and $\mathrm{SO}_{4} / \mathrm{Cl}$ ratios, a positive relationship between $\mathrm{Mg}$ concentrations and $\mathrm{H}_{2} \mathrm{~S}$ concentrations, and a positive relationship between $\mathrm{Mg}$ concentrations and TAs concentrations. This indicates that the TSR extent is high in formation water with high $\mathrm{Mg}$ concentrations, which 


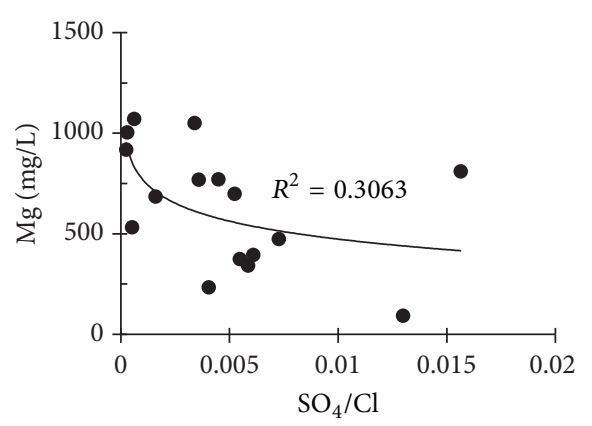

(a)

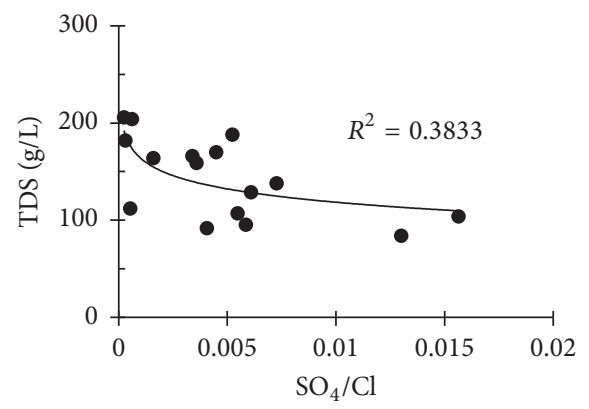

(d)

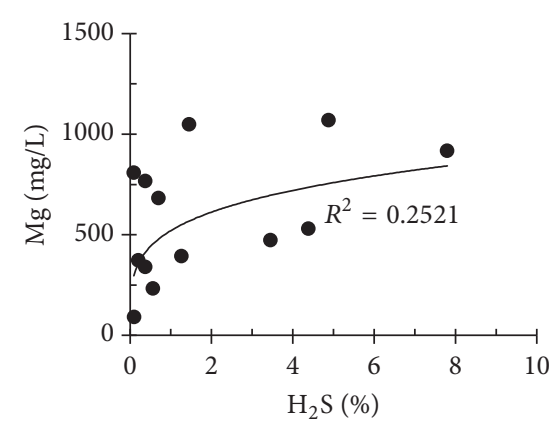

(b)

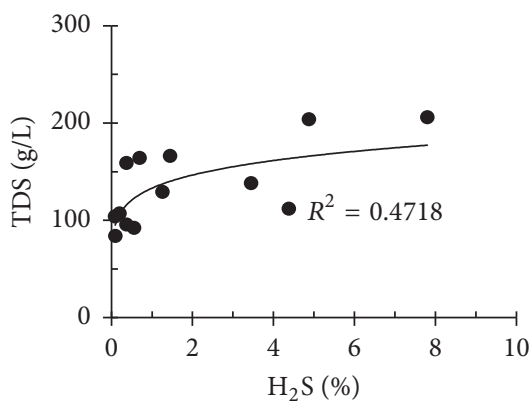

(e)

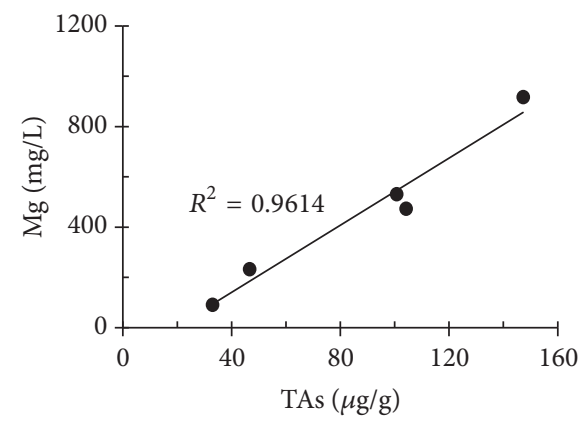

(c)

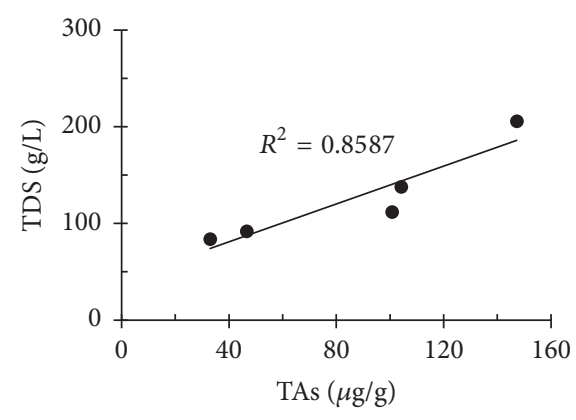

(f)

FIgURE 7: Relationship between (a) $\mathrm{SO}_{4} / \mathrm{Cl}$ ratios and $\mathrm{Mg}$ concentrations; (b) $\mathrm{H}_{2} \mathrm{~S}$ concentrations and $\mathrm{Mg}$ concentrations; (c) TAs concentrations and $\mathrm{Mg}$ concentrations; (d) $\mathrm{SO}_{4} / \mathrm{Cl}$ ratios and TDS; (e) $\mathrm{H}_{2} \mathrm{~S}$ concentrations and TDS; (f) TAs concentrations and TDS.

prove the catalysis of $\mathrm{MgSO}_{4}$. TDS concentrations show a negative correlation with $\mathrm{SO}_{4} / \mathrm{Cl}$ ratios, a positive correlation with $\mathrm{H}_{2} \mathrm{~S}$ concentrations, and a positive correlation with TAs concentrations (Figures 7(d), 7(e), and 7(f)). This also indicates the catalysis of $\mathrm{MgSO}_{4}$ as $\mathrm{Mg}$ concentration is in proportion to TDS in this study.

Mean $\mathrm{Mg} / \mathrm{Cl}$ ratios in the formation water from the Yingshan Formation is 0.007 , which is similar to that from the Feixianguan Formation (0.009 [44]). But average $\mathrm{Mg} / \mathrm{SO}_{4}$ ratio in the formation water from the Yingshan Formation is 6.24, which is significantly higher than that from the Feixianguan Formation (0.035 [44]). The low $\mathrm{Mg} / \mathrm{SO}_{4}$ ratios in the formation water from the Feixianguan Formation resulted from the high $\mathrm{SO}_{4}$ concentration contributed by anhydrite dissolution. The limitation on TSR initiation from low $\mathrm{Mg} / \mathrm{SO}_{4}$ ratios in the Feixianguan Formation was probably compensated by the high temperature in the reservoir (Figure 3(b)). Similarly, the limitation on TSR initiation from low temperature in the Yingshan Formation was compensated by the high $\mathrm{Mg} / \mathrm{SO}_{4}$ ratios in the formation water. Duration time of TSR in the Feixianguan Formation is much longer than that in the Yingshan Formation as temperature of the Feixianguan Formation has reached $200^{\circ} \mathrm{C}$ since the Middle Jurassic (Figure 3(b)). And reaction rate of TSR in the Feixianguan Formation is also faster than that in the Yingshan Formation. Moreover, contribution of total aqueous $\mathrm{SO}_{4}{ }^{2-}$ in the Feixianguan Formation is more than that in the Yingshan Formation as many anhydrites develop in the Feixianguan Formation. These are probably the main reasons for the lower $\mathrm{H}_{2} \mathrm{~S}$ concentrations in the Tazhong area than that in the northeast Sichuan Basin.

\section{Conclusions}

Formation water is the solvent for sulfates, and water chemistry has a great influence on TSR which explain the low TSR extent in the Tazhong area.

(1) $\mathrm{MgSO}_{4}$ contact ion pair in formation water is catalyst for TSR. High $\mathrm{Mg} / \mathrm{SO}_{4}$ ratios and high temperatures are preferable to form $\mathrm{MgSO}_{4}$ contact ion pair in solutions and thus will increase TSR extent. High $\mathrm{Mg} / \mathrm{SO}_{4}$ ratios of the $\mathrm{O}_{1-2} \mathrm{y}$ formation water compensated the low temperature which would limit the initiation of TSR in the Tazhong area.

(2) The lower TSR extent in the Tazhong area is limited by the shorter reaction time and less total aqueous $\mathrm{SO}_{4}{ }^{2-}$ contribution in the reservoir.

\section{Conflicts of Interest}

The authors declare that there are no conflicts of interest regarding the publication of this paper.

\section{Acknowledgments}

This work is supported by the Natural Science Foundation of China (Grants nos. 41672143, 41730424, and 41502148) and Special Major Project on Petroleum Study (2017ZX05008003040).

\section{References}

[1] W. L. Orrm, "Changes in sulfur content and isotopic ratios of sulfur during petroleum maturation-study of the Big Horn 
Basin Paleozoic oils," AAPG Bulletin, vol. 50, pp. 2295-2318, 1974.

[2] H. R. Krouse, C. A. Viau, L. S. Eliuk, A. Ueda, and S. Halas, "Chemical and isotopic evidence of thermochemical sulphate reduction by light hydrocarbon gases in deep carbonate reservoirs," Nature, vol. 333, no. 6172, pp. 415-419, 1988.

[3] R. Sassen, "Geochemical and carbon isotopic studies of crude oil destruction, bitumen precipitation, and sulfate reduction in the deep Smackover Formation," Organic Geochemistry, vol. 12, no. 4, pp. 351-361, 1988.

[4] E. Heydari, C. H. Moore, and R. Sassen, "Late burial diagenesis driven by thermal-degradation of hydrocarbons and thermochemical sulfate reduction-upper Smackover carbonates, southeast Mississippi salt basin," AAPG Bulletin, vol. 72, p. 197, 1988.

[5] H. G. Machel, H. R. Krouse, and R. Sassen, "Products and distinguishing criteria of bacterial and thermochemical sulfate reduction," Applied Geochemistry, vol. 10, no. 4, pp. 373-389, 1995.

[6] R. H. Worden and P. C. Smalley, "H2S-producing reactions in deep carbonate gas reservoirs: Khuff Formation, Abu Dhabi," Chemical Geology, vol. 133, no. 1-4, pp. 157-171, 1996.

[7] C. F. Cai, R. H. Worden, S. H. Bottrell, L. Wang, and C. Yang, "Thermochemical sulphate reduction and the generation of hydrogen sulphide and thiols (mercaptans) in Triassic carbonate reservoirs from the Sichuan Basin, China," Chemical Geology, vol. 202, no. 1-2, pp. 39-57, 2003.

[8] Y. J. Fu, W. van Berk, and H. M. Schulz, "Hydrogen sulfide formation, fate, and behavior in anhydrite-sealed carbonate gas reservoirs: a three-dimensional reactive mass transport modeling approach," AAPG Bulletin, vol. 100, no. 5, pp. 843865, 2016.

[9] C. F. Cai, K. Li, M. Anlai et al., "Distinguishing Cambrian from Upper Ordovician source rocks: Evidence from sulfur isotopes and biomarkers in the Tarim Basin," Organic Geochemistry, vol. 40, no. 7, pp. 755-768, 2009.

[10] C. F. Cai, C. Zhang, L. Cai et al., "Origins of Palaeozoic oils in the Tarim Basin: Evidence from sulfur isotopes and biomarkers," Chemical Geology, vol. 268, no. 3-4, pp. 197-210, 2009.

[11] S. Hanin, P. Adam, I. Kowalewski, A.-Y. Huc, B. Carpentier, and P. Albrecht, "Bridgehead alkylated 2-thiaadamantanes: Novel markers for sulfurisation processes occurring under high thermal stress in deep petroleum reservoirs," Chemical Communications, vol. 16, pp. 1750-1751, 2002.

[12] Z. Wei, P. Mankiewicz, C. Walters et al., "Natural occurrence of higher thiadiamondoids and diamondoidthiols in a deep petroleum reservoir in the Mobile Bay gas field," Organic Geochemistry, vol. 42, no. 2, pp. 121-133, 2011.

[13] C. F. Cai, A. Amrani, R. H. Worden et al., "Sulfur isotopic compositions of individual organosulfur compounds and their genetic links in the Lower Paleozoic petroleum pools of the Tarim Basin, NW China," Geochimica et Cosmochimica Acta, vol. 182, pp. 88-108, 2016.

[14] C. F. Cai, Q. Xiao, C. Fang, T. Wang, W. He, and H. Li, "The effect of thermochemical sulfate reduction on formation and isomerization of thiadiamondoids and diamondoids in the Lower Paleozoic petroleum pools of the Tarim Basin, NW China," Organic Geochemistry, vol. 101, pp. 49-62, 2016.

[15] A. Amrani, T. Zhang, Q. Ma, G. S. Ellis, and Y. Tang, "The role of labile sulfur compounds in thermochemical sulfate reduction," Geochimica et Cosmochimica Acta, vol. 72, no. 12, pp. 29602972, 2008.
[16] W. G. Toland, "Oxidation of organic compounds with aqueous sulfate," Journal of the American Chemical Society, vol. 82, no. 8, pp. 1911-1916, 1960.

[17] Q. Ma, G. S. Ellis, A. Amrani, T. Zhang, and Y. Tang, "Theoretical study on the reactivity of sulfate species with hydrocarbons," Geochimica et Cosmochimica Acta, vol. 72, no. 18, pp. 45654576, 2008.

[18] X. Wang, I.-M. Chou, W. Hu, and R. C. Burruss, "In situ observations of liquid-liquid phase separation in aqueous $\mathrm{MgSO}_{4}$ solutions: geological and geochemical implications," Geochimica et Cosmochimica Acta, vol. 103, pp. 1-10, 2013.

[19] Y. Wan, X. L. Wang, W. X. Hu, and I.-M. Chou, "Raman spectroscopic observations of the ion association between $\mathrm{Mg}^{2+}$ and $\mathrm{SO}_{4}^{2-}$ in $\mathrm{MgSO}_{4}$-saturated droplets at temperatures of $\leq 380^{\circ} \mathrm{C}$," The Journal of Physical Chemistry A, vol. 119, no. 34, pp. 9027-9036, 2015.

[20] C. F. Cai, W. Hu, and R. H. Worden, "Thermochemical sulphate reduction in Cambro-Ordovician carbonates in Central Tarim," Marine and Petroleum Geology, vol. 18, no. 6, pp. 729-741, 2001.

[21] C. F. Cai, G. Y. Hu, H. X. Li et al., "Origins and fates of $\mathrm{H}<\mathrm{inf}>2</$ inf $>\mathrm{S}$ in the Cambrian and Ordovician in Tazhong area: evidence from sulfur isotopes, fluid inclusions and production data," Marine and Petroleum Geology, vol. 67, pp. 408418, 2015.

[22] B. K. Manzano, M. G. Fowler, and H. G. Machel, “The influence of thermochemical sulphate reduction on hydrocarbon composition in Nisku reservoirs, Brazeau river area, Alberta, Canada," Organic Geochemistry, vol. 27, no. 7-8, pp. 507-521, 1997.

[23] C. F. Cai, Z. Xie, R. H. Worden, G. Hu, L. Wang, and H. He, "Methane-dominated thermochemical sulphate reduction in the Triassic Feixianguan Formation East Sichuan Basin, China: Towards prediction of fatal $\mathrm{H}_{2} \mathrm{~S}$ concentrations," Marine and Petroleum Geology, vol. 21, no. 10, pp. 1265-1279, 2004.

[24] G. Y. Zhu, J. F. Chen, G. A. Fei, J. Zhao, and C. Liu, "Sulfur isotopic fractionation and mechanism for Thermochemical Sulfate Reduction genetic $\mathrm{H}_{2}$ S," Acta Petrologica Sinica, vol. 30, no. 12, pp. 3772-3778, 2014.

[25] S. Zhang, J. Su, H. Huang et al., "Genetic origin of sour gas condensates in the Paleozoic dolomite reservoirs of the Tazhong Uplift, Tarim Basin," Marine and Petroleum Geology, vol. 68, pp. 107-119, 2015.

[26] J. Su, S. C. Zhang, H. P. Huang et al., "New insights into the formation mechanism of high hydrogen sulfide-bearing gas condensates: case study of Lower Ordovician dolomite reservoirs in the Tazhong uplift, Tarim Basin," AAPG Bulletin, vol. 100, no. 6, pp. 893-916, 2016.

[27] X.-X. Lu, Z.-J. Jin, L.-F. Liu et al., "Oil and gas accumulations in the Ordovician carbonates in the Tazhong Uplift of Tarim Basin, west China," Journal of Petroleum Science and Engineering, vol. 41, no. 1-3, pp. 109-121, 2004.

[28] C. F. Cai, S. G. Franks, and P. Aagaard, "Origin and migration of brines from Paleozoic strata in Central Tarim, China: constraints from ${ }^{87} \mathrm{Sr} /{ }^{86} \mathrm{Sr}, \delta \mathrm{d}, \delta^{18} \mathrm{O}$ and water chemistry," Applied Geochemistry, vol. 16, no. 9-10, pp. 1269-1284, 2001.

[29] L. Jia, C. Cai, H. Yang et al., "Thermochemical and bacterial sulfate reduction in the Cambrian and Lower Ordovician carbonates in the Tazhong Area, Tarim Basin, NW China: Evidence from fluid inclusions, C, S, and Sr isotopic data," Geofluids, vol. 15, no. 3, pp. 421-437, 2015. 
[30] Z. Q. Chen and G. R. Shi, "Late paleozoic depositional history of the Tarim basin, northwest China: An integration of biostratigraphic and lithostratigraphic constraints," AAPG Bulletin, vol. 87, no. 8, pp. 1323-1354, 2003.

[31] H. Pang, J. Q. Chen, X. Q. Pang, K. Y. Liu, and C. F. Xiang, "Estimation of the hydrocarbon loss through major tectonic events in the Tazhong area, Tarim Basin, west China," Marine and Petroleum Geology, vol. 38, no. 1, pp. 195-210, 2012.

[32] L. S. Clescerl, A. E. Greenberg, and A. D. Eaton, Standard Methods for the Examination of Water and Wastewater, American Public Health Association, Washington, DC, USA, 20th edition, 1999.

[33] H. Li and C. F. Cai, "Origin and evolution of formation water from the Ordovician carbonate reservoir in the Tazhong area, Tarim Basin, NW China," Journal of Petroleum Science and Engineering, vol. 148, pp. 103-114, 2017.

[34] C. F. Cai, K. Li, H. Li, and B. Zhang, "Evidence for cross formational hot brine flow from integrated ${ }^{87} \mathrm{Sr} /{ }^{86} \mathrm{Sr}$, REE and fluid inclusions of the Ordovician veins in Central Tarim, China," Applied Geochemistry, vol. 23, no. 8, pp. 2226-2235, 2008.

[35] J. G. Wynn, J. B. Sumrall, and B. P. Onac, "Sulfur isotopic composition and the source of dissolved sulfur species in thermo-mineral springs of the Cerna Valley, Romania," Chemical Geology, vol. 271, no. 1-2, pp. 31-43, 2010.

[36] G. E. Claypool and E. A. Mancini, "Geochemical relationships of petroleum in Mesozoic reservoirs to carbonate source rocks of Jurassic Smackover Formation, southwestern Alabama," American Association of Petroleum Geologists Bulletin, vol. 73, no. 7, pp. 904-924, 1989.

[37] M. A. McCaffrey, B. Lazar, and Holland, "The evaporation path of seawater and the coprecipitation of $\mathrm{Br}^{-}$and $\mathrm{K}^{+}$with halite," Journal of Sedimentary Petrology, vol. 57, no. 5, pp. 928-937, 1987.

[38] B. W. Logan, “The Mac Leod evaporite basin, western Australia. Holocene environments, sediments and geological evolution," AAPG Memoir, vol. 44, pp. 1-140, 1987.

[39] Z. Wang, C. Cai, H. Li et al., "Origin of late charged gas and its effect on property of oils in the Ordovician in Tazhong area," Journal of Petroleum Science and Engineering, vol. 122, pp. 8393, 2014.

[40] K. Li, C. Cai, L. Jia et al., "The role of thermochemical sulfate reduction in the genesis of high-quality deep marine reservoirs within the central Tarim Basin, western China," Arabian Journal of Geosciences, vol. 8, no. 7, pp. 4443-4456, 2015.

[41] Z. Wei, C. C. Walters, J. Michael Moldowan et al., "Thiadiamondoids as proxies for the extent of thermochemical sulfate reduction," Organic Geochemistry, vol. 44, pp. 53-70, 2012.

[42] S. C. Zhang, Y. H. Shuai, K. He, and J. K. Mi, "Research on the initiation mechanism of thermochemical sulfate reduction (TSR)," Acta Petrologica Sinica, vol. 28, no. 3, pp. 739-748, 2012.

[43] M. Baghalha and V. G. Papangelakis, "The ion-associationinteraction approach as applied to aqueous $\mathrm{H}_{2} \mathrm{SO}_{4}-\mathrm{Al}_{2}\left(\mathrm{SO}_{4}\right)_{3}$ $\mathrm{MgSO}_{4}$ solutions at $250^{\circ} \mathrm{C}$," Metallurgical and Materials Transactions B, vol. 29, no. 5, pp. 1021-1030, 1998.

[44] X. Q. Zhao, J. F. Chen, W. Guo, D. X. He, F. R. Chen, and G. Z. Liu, "Geochemical characteristics of oilfield waters with high $\mathrm{H}_{2} \mathrm{~S}$ gas reservoirs in Feixianguan formation, Northeastern Sichuan Basin," Journal of Central South University (Science and Technology), vol. 45, no. 10, pp. 300-309, 2014. 

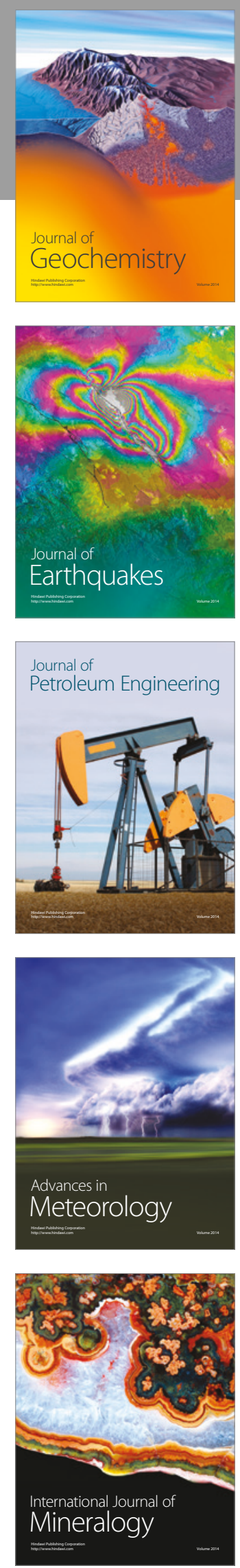
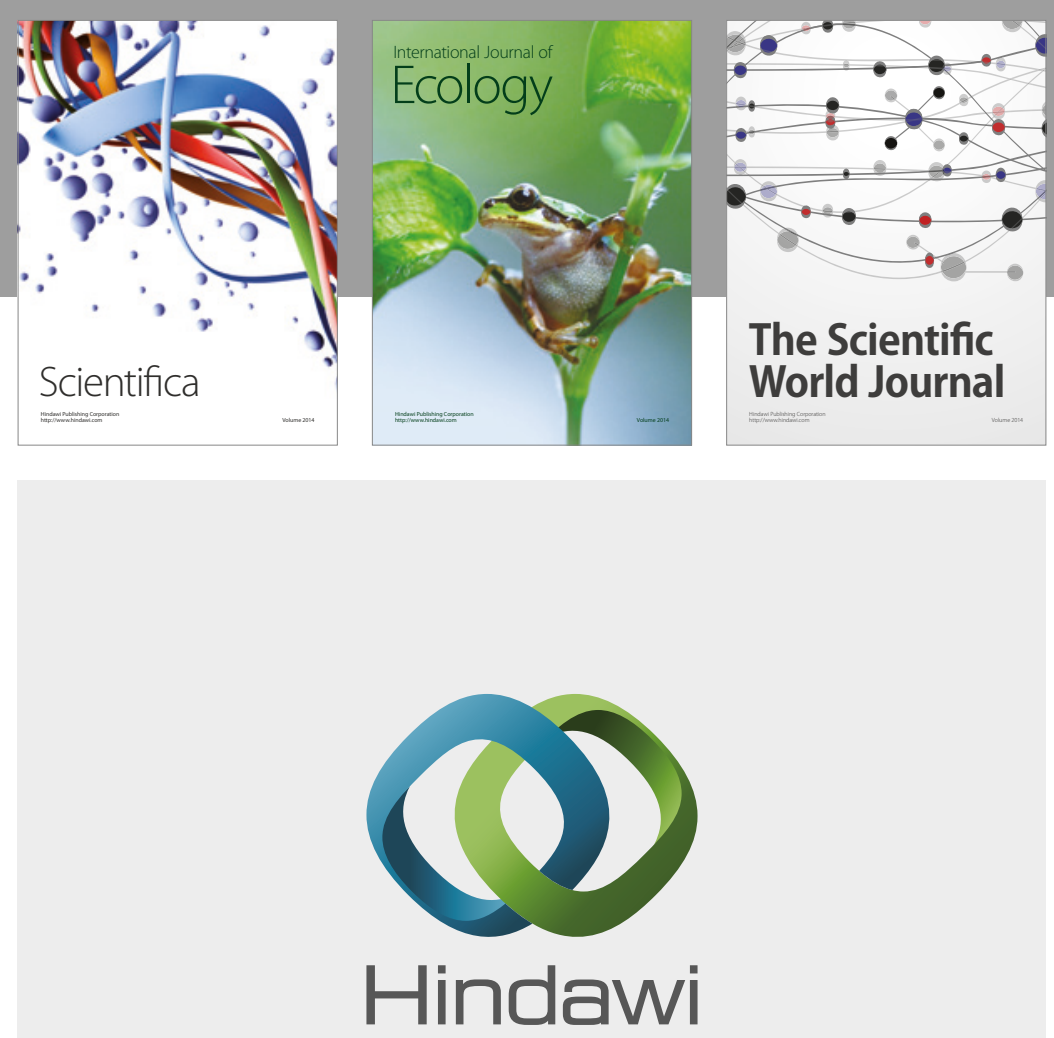

Submit your manuscripts at

https://www.hindawi.com
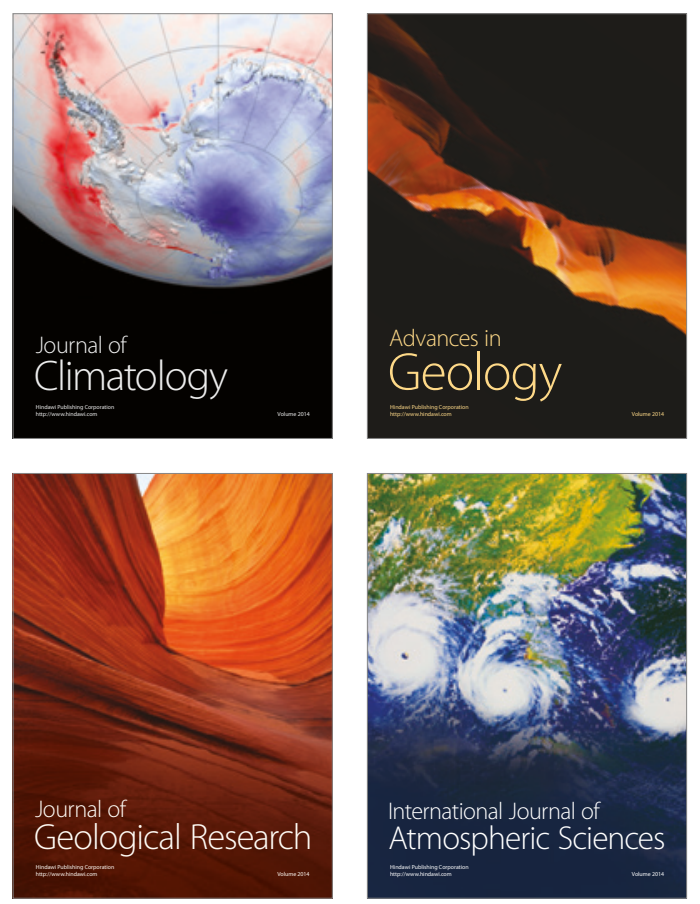

The Scientific

World Journal
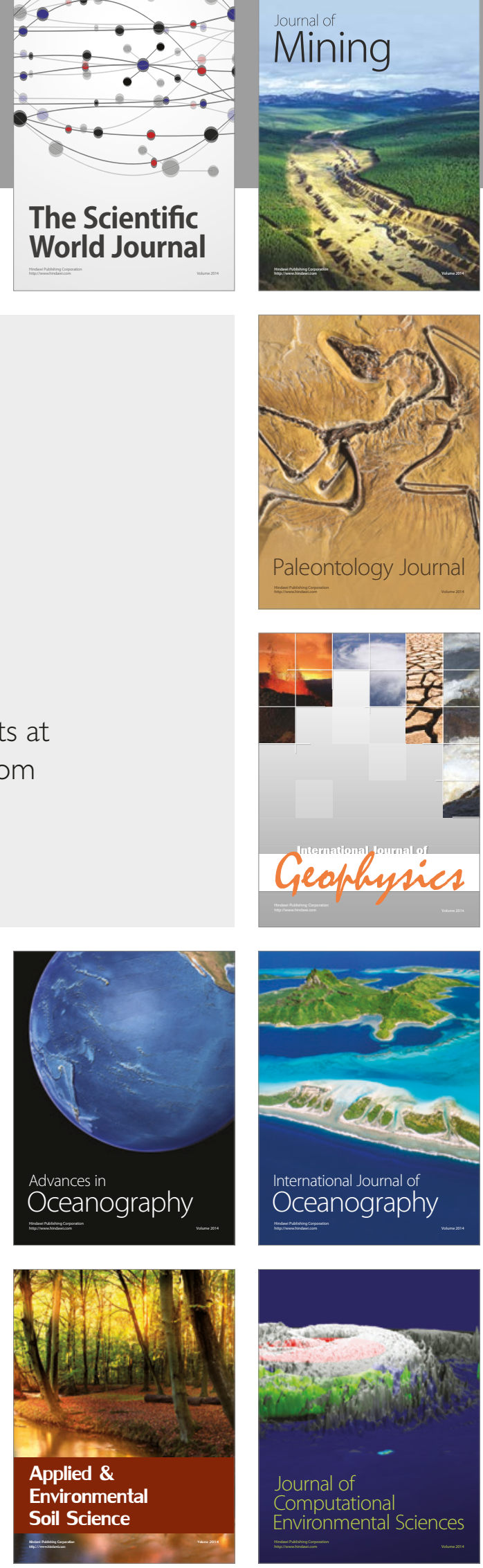